JURNAL GIZI DAN DIETETIK INDONESIA

Vol. 4, No. 3, September 2016: 147-153
Tersedia online pada: http://ejournal.almaata.ac.id/index.php/IJND

DOI : http://dx.doi.org/10.21927/ijnd.2016.4(3).147-153

\title{
Aktivitas antidislipidemia tepung tempe dan susu kedelai pada profil lipid tikus diabetes yang diinduksi streptozotocin
}

\author{
Antidyslipidemic activity of tempe flour and soymilk on lipid profile in streptozotocin-induced diabetic \\ rats
}

Kartika Nugraheni ${ }^{1}$, Siti Harnina Bintari ${ }^{2}$

\begin{abstract}
Background: Dyslipidemia increases risk of cardiovascular disease on diabetes patients. Soybean contains many bioactive compounds which can help to control lipid profile.

Objectives: To analyze the differences effect between tempe flour (fermented soybean) and soymilk (unfermented soybean) on lipid profile in diabetic rats.

Methods: Thirty male Sprague dawley rats divided into 3 groups: diabetic control, tempe flour $1.8 \mathrm{~g}$, and soymilk $1.35 \mathrm{~g}$. Tempe flour and soymilk were given for 28 days. Lipid profile measured including total cholesterol, triglycerides, LDL cholesterol, and HDL cholesterol. The data then were analyzed using Anova with confidence level of $95 \%$.

Results: The decrease values of total cholesterol, triglycerides and LDL cholesterol were more significant in tempe flour group than that were in soymilk. In addition, tempe flour group also showed increase level in HDL cholesterol $(p<0,05)$

Conclusions: Tempe flour (fermented soybean) showed better antidyslipidemic activity than unfermented ones.
\end{abstract}

KEYWORDS: diabetes, dyslipidemia, soymilk, tempe flour

\begin{abstract}
ABSTRAK
Latar belakang: Dislipidemia meningkatkan risiko penyakit kardiovaskuler pada penderita diabetes. Kedelai mengandung berbagai senyawa bioaktif yang dapat membantu mengontrol kadar profil lipid.

Tujuan: Menganalisis perbedaan pengaruh pemberian kedelai yang difermentasi (tepung tempe) dan yang tidak difermentasi (susu kedelai) dalam penurunan kadar profil lipid pada tikus diabetes.

Metode: Tiga puluh ekor tikus sprague dawley jantan dibagi dalam 3 kelompok: kontrol diabetes, pemberian tepung tempe 1,8 gram, dan pemberian susu kedelai 1,35 gram. Intervensi dilakukan setiap hari selama 28 hari melalui sonde. Pemeriksaan kadar profil lipid meliputi kolesterol total, trigliserida, kolesterol LDL dan kolesterol HDL. Perbedaan efektivitas antara tepung tempe dengan susu kedelai dianalisis dengan uji Anova dengan tingkat kemaknaan 95\%.

Hasil: Penurunan kadar kolesterol total, trigliserida dan kolesterol LDL pada kelompok dengan pemberian tepung tempe menunjukkan hasil yang signifikan dibandingkan kelompok pemberian susu kedelai. Peningkatan kadar kolesterol HDL pada kelompok pemberian tepung tempe lebih baik dibandingan pada kelompok dengan pemberian susu kedelai.

Kesimpulan: Tepung tempe menunjukkan aktivitas hipolipidemia yang lebih baik dibandingkan susu kedelai.
\end{abstract}

KATA KUNCI: diabetes, dislipidemia, kedelai, tepung tempe

\footnotetext{
'Department of Nutrition, Faculty of Nursing and Health Sciences, Muhammadiyah University of Semarang, Jl. Kedungmundu Raya No.18, Kedungmundu, Tembalang, Kota Semarang, Jawa Tengah 50273, e-mail: kn.nugraheni@gmail.com

2Department of Biology, Faculty of Mathematics and Sciences, Semarang State University, Jl. Taman Siswa, Sekaran, Gunung Pati, Sekaran, Gn. Pati, Kota Semarang, Jawa Tengah 50229
} 


\section{PENDAHULUAN}

Diabetes melitus (DM) ditandai dengan adanya hiperglikemia kronis yang terjadi karena kelainan sekresi insulin, kerja insulin atau keduanya. Gangguan pada kerja insulin dan hiperglikemia dapat menyebabkan gangguan pada metabolisme karbohidrat, lemak dan protein yang berakibat pada perubahan lipoprotein plasma pada pasien diabetes (1-3) . Istilah diabetik dislipidemia mengacu pada perubahan tiga komponen lipoprotein yaitu peningkatkan trigliserida dan kolesterol low density lipoprotein (LDL) serta penurunan kolesterol high density lipoprotein (HDL) $(3,4)$.

Penderita diabetes berisiko dua hingga empat kali lipat lebih tinggi terkena penyakit kardiovaskuler (PKV) dibandingkan yang tidak menderita diabetes. Kenyataannya, PKV menjadi penyebab kematian utama penderita diabetes, baik diabetes tipe 1 maupun diabetes tipe 2 (2-4). American Diabetes Association (ADA) merekomendasikan terapi gizi medis dan peningkatan aktivitas fisik pada penderita diabetik dislipidemia (2).

Tempe merupakan salah satu sumber protein nabati yang sering dikonsumsi masyarakat Indonesia. Kandungan protein pada tempe mencapai $19,5 \%$. Jumlah ini relatif tinggi dibandingkan dengan makanan sumber protein hewani seperti daging ayam $(21 \%)$, daging sapi $(20 \%)$, telur $(13 \%)$ dan susu (3\%) (5). Fermentasi pada proses pembuatan tempe dapat meningkatkan kualitas organoleptik dan nilai gizi, dibandingkan kedelai yang diolah dengan proses yang berbeda (6). Penelitian Kwon et al (2006) menyatakan bahwa fermentasi pada proses pembuatan tempe meningkatkan daya cerna zat gizi yang terkandung didalamnya serta meningkatkan bioavabilitas isoflavon. Selama proses fermentasi berlangsung isoflavon mengalami perubahan struktur dari glikosida menjadi aglikon, sedangkan protein dipecah menjadi peptida dan asam amino (7).

Protein dan isoflavon tempe telah banyak diteliti manfaatnya terhadap kesehatan. Aktivitas antibakteri pada tempe dapat membantu menanggulangi diare pada anak-anak (6). Tempe rendah akan kandungan asam lemak jenuh yang mampu membantu menurunkan kadar kolesterol total dan LDL. Protein kedelai juga mampu melindungi tulang dari kerapuhan, terutama bagi wanita post-menopause yang berisiko tinggi terkena osteoporosis (8). Isoflavon tempe dapat meningkatkan apoptosis dan menurunkan aktivitas proliferasi pada kanker payudara (9). Selain itu, isoflavon tempe juga dapat mengontrol kadar gula darah dan melindungi sel beta pankreas dari kerusakan lebih lanjut akibat diabetes melitus (10). Berdasarkan latar belakang tersebut, penelitian ini bertujuan untuk menganalisis efek konsumsi tempe dan susu kedelai terhadap parameter profil lipid pada tikus yang dikondisikan hiperglikemia.

\section{BAHAN DAN METODE}

Penelitian ini merupakan penelitian eksperimental dengan desain post-test only randomized controlled group trial. Hewan model yang digunakan adalah tikus putih galur Sprague dawley usia 7-8 minggu dengan berat badan berkisar antara $180-200$ gram. Tikus yang digunakan berjumlah 30 ekor yang dibagi secara acak dalam 3 kelompok.

Kelompok pertama adalah kelompok kontrol negatif (K-), tikus yang diinduksi streptozotocin-NA dan diberi pakan standar. Kelompok kedua adalah tikus yang diinduksi streptozotocin-NA, diberi pakan standar dan sonde tepung tempe (P1). Kelompok ketiga adalah tikus yang diinduksi streptozotocinNA, diberi pakan standar dan sonde susu kedelai (P2). Induksi streptozotocin-NA diberikan dengan dosis $65 \mathrm{mg} / \mathrm{kgBB}$ streptozotocin dan $230 \mathrm{mg} / \mathrm{kgBB}$ NA secara intraperitoneal. Hewan model dianggap hiperglikemia apabila kadar gula darah puasa $\geq$ $200 \mathrm{mg} / \mathrm{dL}$. Pakan standar yang digunakan dalam penelitian ini adalah AIN-93M yang mengacu pada formula Reeves (1993) (11). Tepung tempe dan susu kedelai masing-masing diberikan sebanyak $1,8 \mathrm{gram} / 200 \mathrm{gram}$ dan $1,35 \mathrm{gram} / 200 \mathrm{gram}$ berat badan/hari. Tepung tempe dan susu kedelai diberikan secara oral setelah dilarutkan dalam 3 $\mathrm{mL}$ aquades.

Pemberian tempe dan susu kedelai bubuk dilakukan selama 4 minggu. Penelitian dilakukan 
di Laboratorium Pangan dan Gizi, Pusat Antar Universitas, Universitas Gadjah Mada. Pada akhir minggu keempat, tikus dipuasakan untuk diambil serum darah guna pemeriksaan kadar gula darah, profil lipid dan insulin. Sisa pakan ditimbang setiap hari, sedangkan pengukuran berat badan dilakukan satu minggu sekali. Seluruh metode dalam penelitian ini telah disetujui oleh komisi etik Fakultas Kedokteran Universitas Diponegoro berdasarkan surat komisi etik nomor No. 026/EC/ FK-RSDK/2014.

Tempe dan susu kedelai yang digunakan dibuat dari kedelai lokal varietas Grobogan. Proses pembuatan tempe menggunakan metode yang dikembangkan oleh Bintari (2013) yang kemudian dikeringkan selama 18 jam dan ditepungkan (12). Susu kedelai bubuk diperoleh dari hasil penyangraian kedelai yang kemudian ditepungkan.

Pemeriksaan kadar gula darah, profil lipid dan insulin dilakukan setelah tikus dipuasakan \pm 18 jam. Profil lipid diperiksa secara enzimatik dengan menggunakan reagen dari Human. Kadar Insulin diperiksa dengan metode ELISA dengan kit insulin nomor EIA-2048 dari DRG, Jerman. Pemeriksaan kadar profil lipid dilakukan di Laboratorium Pangan dan Gizi, Pusat Antar Universitas, Universitas Gadjah Mada, sedangkan pemeriksaan kadar insulin dilakukan di Laboratorium GAKI, Cebior, Fakultas Kedokteran, Universitas Diponegoro, Semarang.

Data yang diperoleh diuji normalitas dan homogenitas. Uji normalitas menggunakan ShapiroWilk. Untuk mengetahui adanya perbedaan diantara tiga kelompok perlakuan, dilakukan uji beda One Way Anova dengan uji lanjut $L S D$. Data diolah dengan menggunakan program SPSS versi 20 .

\section{HASIL}

\section{Hewan model}

Hewan model menunjukkan tanda hiperglikemi lima hari pasca induksi streptozotocin-Na. Tidak ada hewan model yang mati pasca induksi. Gula darah puasa seluruh hewan model pasca induksi menunjukkan nilai $>200 \mathrm{mg} / \mathrm{dL}$. Hasil analisis berat badan awal sebelum induksi streptozotocin$\mathrm{Na}$ menunjukkan nilai yang homogen dan normal dengan nilai $p>0,05$ (Tabel 1).

Perubahan berat badan dipantau secara berkala sebelum induksi, pasca induksi, dan tiap minggu selama perlakuan berlangsung (Tabel 1). Pasca induksi streptozotocin- $\mathrm{Na}$, kelompok kontrol yang tidak menerima perlakuan, mengalami penurunan berat badan yang signifikan setiap minggunya $(p<0,05)$. Kelompok P1 dan P2 mengalami penurunan berat badan pasca induksi streptozotocin-Na. Setelah pemberian perlakuan berupa tepung tempe dan susu kedelai kedua kelompok tersebut perlahan-lahan menunjukkan peningkatan berat badan yang signifikan $(p<0,05)$.

Rerata berat badan tikus yang diberi tepung tempe dan susu kedelai lebih tinggi dibandingkan dengan rerata berat badan tikus pada kelompok kontrol. Peningkatan berat badan pada kelompok yang diberi tepung tempe mencapai $13,7 \%$ dan $9,5 \%$ pada kelompok susu kedelai. Perubahan berat

Tabel 1. Rerata berat badan tikus selama penelitian

\begin{tabular}{lccc}
\hline \multicolumn{1}{c}{$\begin{array}{c}\text { Berat badan } \\
\text { (BB) }\end{array}$} & Kontrol & Tepung Tempe & Susu Kedelai \\
\cline { 2 - 4 } & $155,2 \pm 37,2$ & $156,5 \pm 19,6$ & $182,9 \pm 20,3$ \\
\hline Adaptasi & $160,5 \pm 37,5$ & $158,6 \pm 19,4$ & $184,8 \pm 21,0$ \\
DM & $164,6 \pm 37,5$ & $163,1 \pm 19,5$ & $189,0 \pm 20,4$ \\
Perlakuan minggu ke-1 & $160,5 \pm 37,9$ & $170,2 \pm 19,3$ & $194,2 \pm 20,8$ \\
Perlakuan minggu ke-2 & $158,3 \pm 37,3$ & $177,2 \pm 19,3$ & $199,7 \pm 20,1$ \\
Perlakuan minggu ke-3 & $155,4 \pm 37,1$ & $183,8 \pm 19,6$ & $204,2 \pm 20,5$ \\
Perlakuan minggu ke-4 & $-5,1$ & 25,2 & 19,4 \\
$\Delta$ BB & $0,000^{*}$ & $0,000^{*}$ & $0,005^{*}$ \\
\hline
\end{tabular}

$\Delta$ : selisih rerata berat badan DM dan perlakuan minggu ke-4

${ }^{*}$ ) Menunjukkan peerbedaan nyata antara sebelum (pre test) dan sesudah perlakuan (post test), berdasarkan uji Paired $t$-test $(p<0,05)$ 
badan yang terjadi pasca pemberian tepung tempe dan susu kedelai signifikan $(p<0,05)$.

Tempe dan susu kedelai merupakan contoh pangan olahan kedelai. Manfaat konsumsi kedelai berhubungan erat dengan tingginya kandungan protein, asam lemak esensial, vitamin, mineral, isoflavon dan serat. Produk turunan kedelai diduga mempunyai efek langsung terhadap proses metabolisme tubuh. Genistein dan daidzein, isoflavon utama yang terdapat pada kedelai, terbukti dapat terikat pada reseptor PPAR, terutama PPAR $\mathrm{Y}$, a dan $\delta$. PPAR $\alpha$ mengontrol transkripsi gen yang terlibat dalam katabolisme lemak, sedangkan PPARy mengontrol ekspresi gen yang terlibat dalam diferensiasi sel lemak dan sensitivitas insulin.

Kelompok kontrol mengalami peningkatan asupan energi yang signifikan selama penelitian berlangsung $(p<0,05)$ (Tabel 2). Tidak ada peningkatan konsumsi pakan yang signifikan pada kelompok perlakuan tepung tempe dan susu kedelai ( $p>0,05)$ (Tabel 2). Peningkatan asupan energi pada kelompok kontrol menunjukkan salah satu gejala khas hiperglikemia yaitu polyphagia.

\section{Kadar profil lipid}

Rerata kadar kolesterol total pada kelompok kontrol, tepung tempe dan susu kedelai masingmasing adalah 159,8 mg/dL; $97,7 \mathrm{mg} / \mathrm{dL}$; dan $128,4 \mathrm{mg} / \mathrm{dL}$. Hasil uji statistik menunjukkan ada perbedaan signifikan pada ketiga kelompok tersebut $(p<0,05)$. Penurunan kadar kolesterol total tertinggi terdapat pada kelompok yang diberi tepung tempe $(p<0,05)$ (Tabel 3).
Rerata kadar trigliserida dan kolesterol LDL tertinggi ada pada kelompok kontrol dengan nilai sebesar 84,7 mg/dL dan 63,0 mg/dL. Ada perbedaan signifikan antara rerata kadar trigliserida dan kolesterol LDL pada kelompok tepung tempe dan susu kedelai. Rerata kadar trigliserida dan kolesterol LDL terendah ada di kelompok tempe dengan nilai sebesar 43,0 mg/dL dan 21,2 mg/dL. Kelompok tepung tempe dengan pemberian tepung tempe menunjukkan nilai kolesterol HDL terbaik diantara seluruh kelompok dengan nilai 45,9 mg/dL (Tabel 3) dibandingkan rerata kolesterol HDL pada kelompok susu kedelai.

\section{Kandungan gizi dan isoflavon pada tempe dan susu kedelai}

Standar diet diabetes melitus menganjurkan asupan protein nabati 2-3 satuan penukar per hari (13). Penelitian ini menggunakan standar 3 satuan penukar protein nabati yang setara dengan 150 gram tempe atau 75 gram kedelai (14). Jumlah tersebut kemudian dikonversi menggunakan tabel konversi Laurence dan Bacharach (1964) sehingga diperoleh 2,7 gram tempe dan 1,35 gram kedelai. Pengolahan tempe menjadi tepung menimbulkan susut kuantitatif sebanyak $1 / 3$ berat awal sehingga diperoleh dosis tepung tempe sebanyak 1,8 gram. Kandungan isoflavon yang terdapat dalam 150 gram tempe adalah sekitar 154,05 mg dan 160,5 mg pada 75 gram kedelai. Hasil uji proksimat dan uji flavonoid tepung tempe dan susu kedelai dapat dilihat pada Tabel 4.

Tabel 2. Rerata asupan pakan tikus selama penelitian

\begin{tabular}{lccccc}
\hline \multirow{2}{*}{ Kelompok } & \multicolumn{2}{c}{ Pakan (gram) } & \multicolumn{2}{c}{ Asupan energi (kkal) } & \multirow{2}{*}{ p } \\
\cline { 2 - 5 } & Pre test & Post test & Pre test & Post test & \\
\hline Kontrol & $17,40 \pm 0,24$ & $17,94 \pm 0,60$ & 68,73 & 70,863 & 0,017 \\
Tepung tempe & $16,97 \pm 0,75$ & $16,90 \pm 0,44$ & 67,03 & 66,75 & 0,839 \\
Susu kedelai & $16,54 \pm 0,56$ & $16,47 \pm 0,75$ & 65,33 & 65,05 & 0,799 \\
\hline
\end{tabular}

Tabel 3. Profil lipid pasca pemberian tepung tempe dan susu kedelai

\begin{tabular}{lcccc}
\hline Kelompok & $\begin{array}{c}\text { Kolesterol Total } \\
(\mathbf{m g} / \mathbf{d L})\end{array}$ & $\begin{array}{c}\text { Trigliserida (mg/ } \\
\mathbf{d L})\end{array}$ & $\begin{array}{c}\text { Kolesterol LDL } \\
\text { (mg/dL) }\end{array}$ & $\begin{array}{c}\text { Kolesterol HDL } \\
\text { (mg/dL) }\end{array}$ \\
\hline Kontrol & 159,8 & 84,7 & 63,0 & 24,4 \\
Tepung tempe (p1) & 97,7 & 45,9 & 21,2 & 45,9 \\
Susu kedelai (p2) & 128,4 & 61,7 & 43,8 & 32,8 \\
\hline
\end{tabular}


Tabel 4. Kandungan gizi dan flavonoid tepung tempe dan susu kedelai

\begin{tabular}{cccccc}
\hline & $\begin{array}{c}\text { Air } \\
(\mathbf{\%})\end{array}$ & $\begin{array}{c}\text { Abu } \\
\mathbf{( \% )}\end{array}$ & $\begin{array}{c}\text { Lemak } \\
\mathbf{( \% )}\end{array}$ & $\begin{array}{c}\text { Protein } \\
(\mathbf{\%})\end{array}$ & $\begin{array}{c}\text { Flavonoid } \\
\text { (ppm) }\end{array}$ \\
\hline \multirow{2}{*}{ Tepung tempe } & 5,61 & 2,69 & 22,12 & 41,36 & 69,46 \\
& 5,20 & 2,63 & 22,79 & 40,79 & 72,24 \\
\multirow{2}{*}{ Susu kedelai } & 4,58 & 4,75 & 19,99 & 31,71 & 16,74 \\
& 4,75 & 4,88 & 19,89 & 31,74 & 19,53 \\
\hline
\end{tabular}

\section{BAHASAN}

Dislipidemia meningkatkan risiko penyakit kardiovaskuler pada penderita diabetes. Hingga saat ini, statin menjadi lini pertama untuk mengatasi dislipidemia terutama dalam menurunkan kadar kolesterol LDL yang bersifat aterogenik (15). Diabetes dapat menyebabkan kerusakan pada sistem kardiovaskuler melalui berbagai macam cara. Proses tersebut tidak berkembang secara mandiri karena penyakit diabetes maupun penyakit kardiovaskuler dapat mempercepat atau memperburuk kondisi satu sama lain. Penderita diabetes yang terkena serangan jantung ataupun stroke memiliki prognosis yang lebih buruk dibandingkan mereka yang tidak terkena diabetes (16).

Penanganan dislipidemia pada penderita diabetes secara komprehensif melalui modifikasi gaya hidup yang meliputi terapi diet, olahraga, dan menurunkan berat badan berlebih serta disertai dengan terapi obat seperti statin atau fibrat dapat menurunkan risiko penyakit jantung koroner serta mencegah terjadinya stroke dan penyakit vaskuler lainnya (16). Penggunaan pangan fungsional sebagai salah satu langkah terapi gizi medis dapat meningkatkan efektivitas dalam penatalaksanaan diet pada pasien DM tipe 2. Potensi kedelai sebagai pangan fungsional dalam kasus diabetes disebabkan adanya kandungan fitoesterogen isoflavon (genistein, daidzein, glisitein) yang mempunyai efek positif terhadap kontrol glikemik, sensitivitas insulin, dislipidemia, dan fungsi ginjal (17).

Konsumsi kedelai dan tempe terbukti dapat membantu mengontrol kadar gula darah serta memiliki efek insulinotropik pada tikus yang diinduksi streptozotocin (10). Penelitian tersebut membuktikan bahwa konsumsi kedelai pada tikus diabetes terbukti dapat membantu mengontrol kadar profil lipid secara signifikan. Penelitian serupa yang membandingkan efektivitas doenjang, pasta kedelai hasil fermentasi dari Korea Selatan, dengan kedelai memberikan kesimpulan yang sama dengan penelitian ini. Kedelai yang telah melalui proses fermentasi memiliki kadar isoflavon aglikon yang jauh lebih tinggi dibandingkan dengan kedelai yang tidak difermentasi. Perbedaan kadar isoflavon aglikon inilah yang membedakan penurunan kadar profil lipid (18).

Berbagai mekanisme potensi kedelai terhadap perbaikan kadar profil lipid telah dikemukakan. Kandungan protein dan berbagai senyawa bioaktif pada kedelai bersinergi dalam memberikan efek terapeutik kedelai terhadap kesehatan. Mekanisme aktivitas hipolipidemik kedelai hingga saat ini belum diketahui secara pasti. Secara garis besar, mekanisme yang mendasari efek hipolipidemik kedelai meliputi: penghambatan sintesis kolesterol endogen, stimulasi ekskresi asam empedu melalui feses oleh serat kedelai, dan aktivasi reseptor LDL oleh asam amino esensial oleh protein kedelai $(19,20)$.

Kandungan zat gizi dan senyawa bioaktif lain yang ada pada kedelai juga berperan dalam penurunan kadar profil lipid. Protein kedelai memiliki komponen bioaktif yang secara langsung maupun tidak langsung berinteraksi dengan gen yang berperan dalam metabolisme lemak di hati, sehingga dapat memodulasi kadar profil lipid. Penelitian pada hewan coba menunjukkan efek hipotrigliseridemia protein kedelai yang dimediasi oleh sterol regulatory element-binding protein-1 (SREBP-1) (21).

Aktivitas hipokolesterol dari protein kedelai disebabkan oleh rendahnya kandungan asam amino metionin pada kedelai (22). Asupan asam amino metionin berkorelasi positif dengan peningkatan kadar homosistein dan plasma kolesterol. Metionin dapat menginduksi hiperkolesterolemia dengan cara meningkatkan sintesis kolesterol di hati (22). 
Rasio lisin/arginin yang rendah pada kedelai terbukti memiliki aktivitas hipokolesterolemia pada tikus Zucker (23). Peptida bioaktif yang terenkripsi pada sekuensi asam amino, baik sub unit $\alpha$ dan $\beta$ dari $7 S$ globulin meningkatkan aktivitas reseptor LDL pada sel HepG2 (22). Protein dan isoflavon kedelai meningkatkan kadar kolesterol HDL secara signifikan sebanyak 3,03\% (24).

Perbedaan penurunan kadar profil lipid antara kelompok pemberian tepung tempe dan susu kedelai disebabkan oleh bentuk senyawa isoflavon yang terkandung dalam kedua produk tersebut. Isoflavon aglikon yang ada pada tepung tempe memiliki bioavaibilitas yang lebih tinggi dibandingkan isoflavon glikosida pada susu kedelai. Isoflavon diserap oleh tubuh dalam bentuk aglikon. Perubahan bentuk isoflavon glikosida menjadi aglikon pada tempe terjadi selama proses fermentasi dengan bantuan enzim $\beta$-glukosidase yang berasal dari kapang Rhizopus oligosporus. Isoflavon aglikon dapat terdeteksi pada darah 30 menit setelah ingesti dan mencapai kadar puncaknya pada 1 jam pasca ingesti (25-28).

Isoflavon glikosida pada susu kedelai dapat diubah menjadi bentuk aglikon dengan bantuan enzim $\beta$-glukosidase dan enzim lactase phlorizin hydrolase (LPH) yang terdapat pada saluran pencernaan terutama pada usus halus. Konversi isoflavon glikosida menjadi aglikon membutuhkan waktu 2-4 jam pasca ingesti. Isoflavon glikosida mencapai kadar puncaknya 4-8 jam pasca ingesti. Penelitian oleh Piskula et al (1999) menyatakan bahwa genistein dan daidzein lebih mudah diserap dibandingkan bentuk glikosida (29). Hal ini membuktikan bahwa isoflavon aglikon pada tepung tempe lebih efektif dalam menurunkan kadar profil lipid dibandingkan isoflavon glikosida pada susu kedelai (25-28).

\section{KESIMPULAN DAN SARAN}

Bentuk sediaan kedelai fermentasi (tepung tempe) menunjukkan aktivitas antidislipidemia yang lebih baik dibandingkan kedelai yang tidak difermentasi (susu kedelai). Proses fermentasi dalam pembuatan tempe meningkatkan bioavaibilitas berbagai senyawa bioaktif yang ada pada kedelai yang bermanfaat dalam perbaikan kadar profil lipid pada kasus diabetes.

\section{RUJUKAN}

1. Goldberg IJ. Diabetic Dyslipidemia: Causes and Consequences. J Clin Endocrinol Metab. 2001 Mar;86(3):965-71.

2. American Diabetes Association. Standards of Medical Care in Diabetes--2010. Diabetes Care. 2010 Jan 1;33(Supplement_1):S11-61.

3. Dixit A, Dey R, Suresh A, Chaudhuri S, Panda A, Mitra A, et al. The prevalence of dyslipidemia in patients with diabetes mellitus of ayurveda Hospital. J Diabetes Metab Disord. 2014;13(1):58.

4. American Diabetes Association. Diagnosis and Classification of Diabetes Mellitus. Diabetes Care. 2011 Jan 1;34(Supplement_1):S62-9.

5. Shurtleff W, Aoyagi A. History of Soybeans and Soyfoods in the Middle East: Extensively Annotated Bibliography and Sourcebook. USA: Soyinfo Center; 2008.

6. Nout MJR, Kiers JL. Tempe fermentation, innovation and functionality: update into the third millenium. J Appl Microbiol. 2005 Apr;98(4):789805.

7. Kwon DY, Jang JS, Lee JE, Kim Y-S, Shin D-H, Park $\mathrm{S}$. The isoflavonoid aglycone-rich fractions of Chungkookjang, fermented unsalted soybeans, enhance insulin signaling and peroxisome proliferator-activated receptor- $\gamma$ activity in vitro. BioFactors. 2006;26(4):245-58.

8. Messina M, Messina V. The Role of Soy in Vegetarian Diets. Nutrients. 2010 Aug 6;2(8):855-88.

9. Harnina Bintari S, Fatimah Moeis S. Perubahan parameter biologik jaringan kanker payudara mencit akibat pemberian isoflavon tempe. Indones J Clin Nutr. 2013;9(4):1-7.

10. Bintari S, Putriningtyas N, Nugraheni K, Widyastiti N, Dharmana E, Johan A. Comparative Effect of Tempe and Soymilk on Fasting Blood Glucose, Insulin Level and Pancreatic Beta Cell Expression (Study on Streptozotocin- 
Induced Diabetic Rats). Pakistan J Nutr. 2015;14(4):239.

11. Reeves PG, Nielsen FH, Fahey GC. AIN93 purified diets for laboratory rodents: final report of the American Institute of Nutrition ad hoc writing committee on the reformulation of the AIN-76A rodent diet. J Nutr. 1993 Nov;123(11):1939-51.

12. Bintari SH. Pasteurization for Hygienic Tempe: Study Case of Krobokan Tempe Yesterday and Today. GSTF J Biosci Vol 2 Number 2. 2013 May;2(2).

13. Sukardji K. Daftar bahan makanan penukar dan perencanaan makan pada diabetes melitus. Pedoman Diet Diabetes Melitus. Jakarta: FKUI; 2007. p. 25-36.

14. Persatuan Ahli Gizi Indonesia \& Bagian Gizi RS Cipto Mangunkusumo. Daftar Penukar Bahan Makanan. Jakarta: Gramedia Pustaka Utama; 2002.

15. Ng DS. Diabetic Dyslipidemia: From Evolving Pathophysiological Insight to Emerging Therapeutic Targets. Can J Diabetes. 2013 Oct;37(5):319-26.

16. International Diabetes Federation. Diabetes and Cardiovascular Disease: Time to Act. USA: Brussels; 2001.

17. Mirmiran P, Bahadoran Z, Azizi F. Functional foods-based diet as a novel dietary approach for management of type 2 diabetes and its complications: A review. World J Diabetes. 2014;5(3):267-81.

18. Kwak CS, Park SC, Song KY. Doenjang , a Fermented Soybean Paste, Decreased Visceral Fat Accumulation and Adipocyte Size in Rats Fed with High Fat Diet More Effectively Than Nonfermented Soybeans. J Med Food. 2012 Jan;15(1):1-9.

19. Cho S-J, Juillerat MA, Lee C-H. Cholesterol Lowering Mechanism of Soybean Protein Hydrolysate. J Agric Food Chem. 2007 Dec;55(26):10599-604.

20. Høie LH, Morgenstern ECA, Gruenwald J, Graubaum H-J, Busch R, L der W, et al. A double-blind placebo-controlled clinical trial compares the cholesterollowering effects of two different soy protein preparations in hypercholesterolemic subjects. Eur J Nutr. 2005;44(2):65-71.

21. Oliva ME, Chicco A, Lombardo YB. Mechanisms underlying the beneficial effect of soy protein in improving the metabolic abnormalities in the liver and skeletal muscle of dyslipemic insulin resistant rats. Eur J Nutr. 2015 Apr 5;54(3):407-19.

22. El Khoury D, Anderson GH. Recent advances in dietary proteins and lipid metabolism. Curr Opin Lipidol. 2013 Jun;24(3):207-13.

23. Gudbrandsen OA, Wergedahl H, Liaset B, Espe $M$, Berge RK. Dietary proteins with high isoflavone content or low methionine-glycine and lysinearginine ratios are hypocholesterolaemic and lower the plasma homocysteine level in male Zucker fa/ fa rats. Br J Nutr. 2005 Sep 8;94(03):321.

24. Yanai H, Katsuyama H, Hamasaki H, Abe S, Tada N, Sako A. Effects of Soy Protein and Isoflavones Intake on HDL Metabolism in Asian Populations. J Endocrinol Metab. 2014;4(3):51-5.

25. Day A, Cañada F, Díaz J, Kroon P, Mclauchlan R, Faulds $\mathrm{C}$, et al. Dietary flavonoid and isoflavone glycosides are hydrolysed by the lactase site of lactase phlorizin hydrolase. FEBS Lett. 2000;468(2-3):166-70.

26. Cassidy A, Brown JE, Hawdon A, Faughnan MS, King LJ, Millward $\mathrm{J}$, et al. Factors affecting the bioavailability of soy isoflavones in humans after ingestion of physiologically relevant levels from different soy foods. J Nutr. 2006 Jan;136(1):4551.

27. Larkin T, Price WE, Astheimer L. The Key Importance of Soy Isoflavone Bioavailability to Understanding Health Benefits. Crit Rev Food Sci Nutr. 2008 May 28;48(6):538-52.

28. Kwon DY, Hong SM, Ahn IS, Kim MJ, Yang HJ, Park S. Isoflavonoids and peptides from meju, long-term fermented soybeans, increase insulin sensitivity and exert insulinotropic effects in vitro. Nutrition. 2011 Feb;27(2):244-52.

29. Izumi T, Piskula MK, Osawa S, Obata A, Tobe $\mathrm{K}$, Saito $\mathrm{M}$, et al. Soy isoflavone aglycones are absorbed faster and in higher amounts than their glucosides in humans. J Nutr. 2000 Jul;130(7):1695-9. 